\title{
Duplication of the Miller-Dieker Critical Region in a Patient with a Subtelomeric Unbalanced Translocation t(10;17)(p15.3;p13.3)
}

\author{
R. Ruiz Esparza-Garrido A.C. Velázquez-Wong M.A. Araujo-Solís \\ J.C. Huicochea-Montiel M.Á. Velázquez-Flores F. Salamanca-Gómez \\ D.J. Arenas-Aranda
}

Unidad de Investigación Médica en Genética Humana (UIMGH), Hospital de Pediatría, Instituto Mexicano del Seguro Social (IMSS), Mexico City, Mexico

\section{Key Words}

Miller-Dieker syndrome critical region - Partial deletion $10 p \cdot$ Partial duplication $17 p \cdot$ Subtelomeres $\cdot$ Unbalanced translocation

\begin{abstract}
Submicroscopic duplications in the Miller-Dieker critical region have been recently described as new genomic disorders. To date, only a few cases have been reported with overlapping 17p13.3 duplications in this region. Also, small deletions that affect chromosome region 10p14 $\rightarrow$ pter are rarely described in the literature. In this study, we describe, to our knowledge for the first time, a 5-year-old female patient with intellectual disability who has an unbalanced 10; 17 translocation inherited from the father. The girl was diagnosed by subtelomeric FISH and array-CGH, showing a 4.43$\mathrm{Mb}$ heterozygous deletion on chromosome 10p that involved 14 genes and a 3.22-Mb single-copy gain on chromosome $17 p$, which includes the critical region of the MillerDieker syndrome and 61 genes. The patient's karyotype wasestablishedas46,XX.arr 10p15.3p15.1(138,206-4,574,436) $\mathrm{x1}, 17 \mathrm{p} 13.3(87,009-3,312,600) \times 3$. Because our patient exhibits a combination of 2 imbalances, she has phenotypic features of both chromosome abnormalities, which have been re-
\end{abstract}

\section{KARGER}

Fax +4161306 1234

E-Mail karger@karger.ch

www.karger.com
(C) 2012 S. Karger AG, Basel

$1661-8769 / 12 / 0032-0082 \$ 38.00 / 0$

Accessible online at:

www.karger.com/msy ported separately. Interestingly, the majority of patients who carry the deletion 10p have visual and auditory deficiencies that are attributed to loss of the GATA3 gene. However, our patient also presents severe hearing and visual problems even though GATA3 is present, suggesting the involvement of different genes that affect the development of the visual and auditory systems.

Copyright $\odot 2012$ S. Karger AG, Basel

Subtelomeres are particular chromosome regions made up of a large number of genes and a high amount of different repetitive sequences [Mefford and Trask, 2002; Riethman et al., 2005]. Due to this structural composition, these regions are involved in chromosome rearrangements [Saccone et al., 1992; De Vries, 2003; Linardopoulou et al., 2005; Ledbetter and Martin, 2007]. The development of advanced molecular cytogenetic methods has allowed for the identification of subtelomeric rearrangements as an important cause of mental retardation and/or congenital malformation [Knight and Flint, 2000]. Some of the subtelomeric chromosome regions with a relatively high proportion of disease-associated rearrangements or copy number variation are subtelomeres of chromosomes $10 p$ and $17 p$

Dr. Diego Julio Arenas-Aranda

Unidad de Investigación en Genética Humana, Centro Médico Nacional Siglo XXI Instituto Mexicano del Seguro Social (IMSS)

Avenida Cuauhtémoc 330, Mexico City 06720 (Mexico)

Tel. +52 555627 6945, E-Mail arenasdi@gmail.com 
[Verri et al., 2004; Linardopoulou et al., 2005; Wu et al., 2010].

In the Miller-Dieker syndrome (MDS) critical region, 17p13.3 microdelections and duplications have been described in different groups of patients with distinct but overlapping phenotypes. In the MDS critical region, some genes are mapped that play an important role during central nervous system development as the plateletactivating factor acetylhydrolase gene (PAFAH1B1), which encodes the LIS1 protein and the candidate gene tyrosine 3-monooxygenase/tryptophan 5-monooxygenase activation protein, epsilon polypeptide (YWHAE), which encodes the 14-3-3 $\varepsilon$ protein. [Assadi et al., 2003; Toyo-oka et al., 2003] When one of these genes is lost or duplicated, patients present brain malformation [Chong et al., 1996, 1997; Cardoso et al., 2000, 2003]. Importantly, microduplications in this region are rare; to date, very few cases have been reported in detail [Ravnan et al., 2006; Lu et al., 2007; Bi et al., 2009; Roos et al., 2009; Bruno et al., 2010; Shchelochkov et al., 2010].

Terminal deletions of chromosome 10p have been published on several occasions [Bourrouillou et al., 1981; Fryns et al., 1981; Suciu and Nanulescu, 1983; Kinoshita et al., 1992; Shapira et al., 1994; Schinzel, 2001; Roos et al., 2006; Battaglia et al., 2007; Lindstrand et al., 2010]; however, only 5 cases with a small deletion that affected the chromosome region 10 p14 $\rightarrow$ pter have been reported [Bourrouillou et al., 1981; Fryns et al., 1981; Lindstrand et al., 2010]. In general, the majority of the pure deletions reported for chromosome 10p are associated with the DiGeorge-like phenotype (DGSII) or with the hypoparathyroidism-sensorineural deafness/renal syndrome (HDR), the latter associated with the GATA3 gene [Schuffenhauer et al., 1995; Dasoiuki et al., 1997; Van Esch et al., 2000; Fukami et al., 2011].

In this study, we report, to our knowledge for the first time, the identification of a patient with a cryptic unbalanced 10;17 translocation identified by subtelomeric FISH and array-CGH. Our results also demonstrate that the unbalanced translocation in the patient was inherited from the father, which has not been reported to date. Likewise, the visual and auditory abnormalities present in our patient are not related to the GATA3 gene.

\section{Clinical Report}

The patient is the second child of healthy, nonconsanguineous Mexican-mestizo parents without a familial history of mental retardation or genetic conditions. Her parents and sister were healthy. She was born at term (38 weeks of gestation) by cesarean

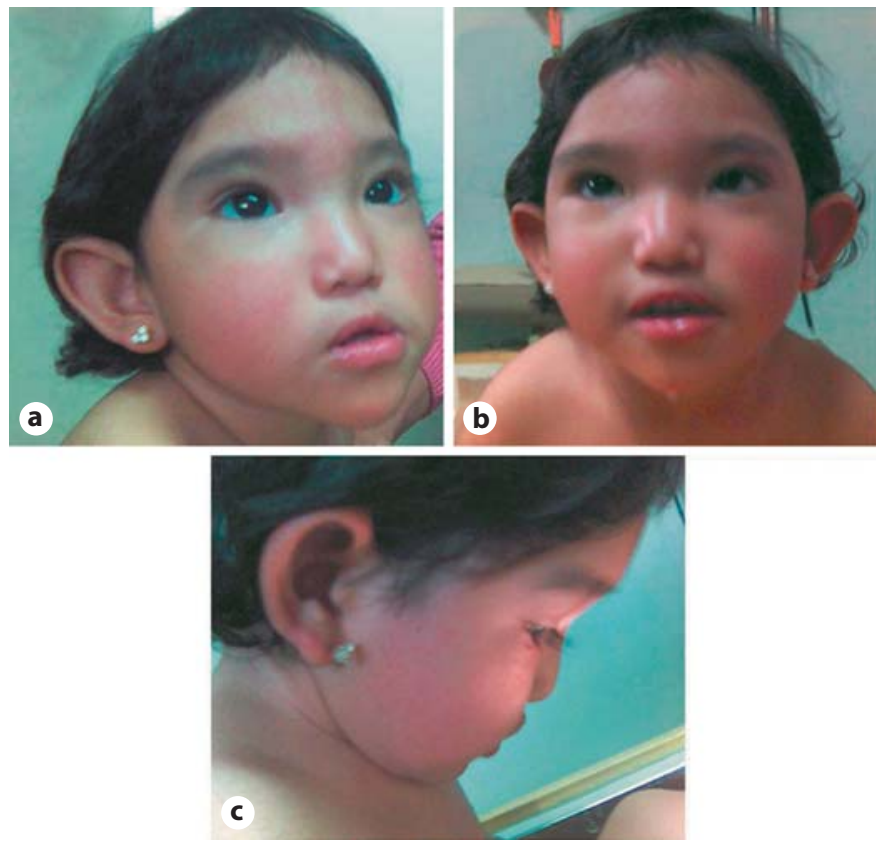

Fig. 1. Patient aged 2 years. a Note some dysmorphic features present in the patient, such as pointed chin, ears with an absent superior fork of the antihelix and frontal hemangioma. $\mathbf{b}$ Image shows hypertelorism, sparse eyebrows, palpebral fissures slanted upward, and bilateral epicanthus. Note the small nose with rounded tip and broad nasal root. $\mathbf{c}$ Lateral photo showing cupped ears and flat facial profile.

section due to fetal distress. Her weight at birth was $3,000 \mathrm{~g}$ (25th percentile). The patient measured $51 \mathrm{~cm}$ in length (50-75th percentile) and had an Apgar score of 8/9 at 1 and 5 min, respectively. At 5 months of age, clinical examination showed medial frontal hemangioma, microcephaly with a head circumference of 37 $\mathrm{cm}(<3 \mathrm{rd}$ percentile) and sagittal synostosis, which did not require surgical intervention. She showed other dysmorphic features, including sloping forehead, flat facial profile, hypertelorism, and sparse eyebrows. The patient presented palpebral fissures, slanted upward, and bilateral epicanthus. The nose was small with rounded tip and a broad nasal root. The ears were cupshaped, with an absent superior fork of the antihelix. Additionally, the patient showed a short philtrum, high-arched palate and short neck (fig. 1,2). She has abnormalities in hands and feet, showing long fingers on both hands, bilateral equinovalgus, clinodactyly of the 4th toe on each foot, dysplastic concave toenails, and reduced extension of the upper and lower extremities. In addition, hyperpigmented skin in the genital area was observed. Xray studies revealed left scoliosis, vertebral bodies with lateral outgrowths and a dysrhythmic bone age. Brain MRI showed cortical atrophy and hypoplasia of corpus callosum (image not shown), whereas evoked potentials indicated severe bilateral visual dysfunction and immaturity of auditory brainstem-evoked responses. Furthermore, the patient has developmental delay and exhibits no verbal language at 5 years of age. 
Fig. 2. Patient aged 5 years. a, b Note facial dysmorphic features that are more noticeable, such as pointed chin, ears with and absent superior fork of the antihelix, palpebral fissures, bilateral epicanthus, strabismus, and broad nasal root.
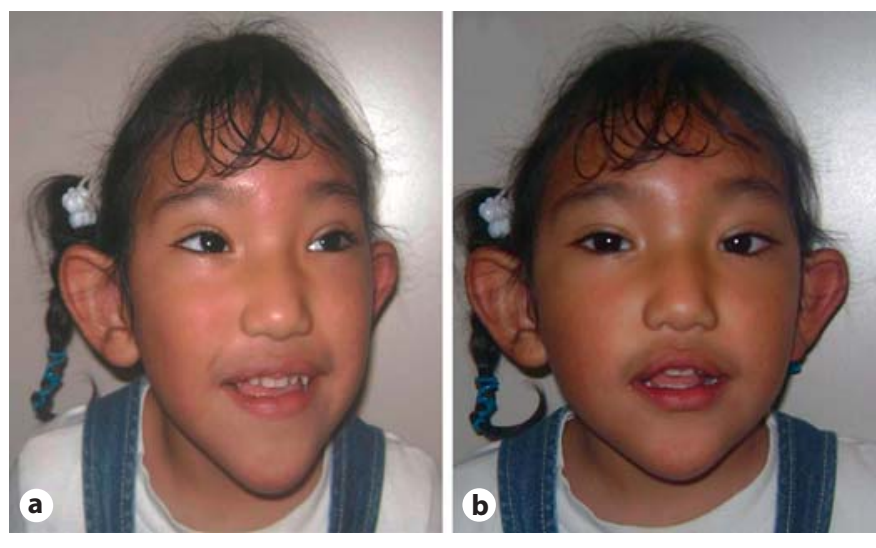

Fig. 3. Partial monosomy 10p and partial trisomy $17 \mathrm{p}$ detected with simultaneous FISH for subtelomeric regions in the patient. a The specific probe shows only 1 signal for chromosome 10, which is involved in the rearrangement. b Three signals for the specific region $17 p$ were detected; the extra signal was found on chromosome 10p, which lost the subtelomeric region.

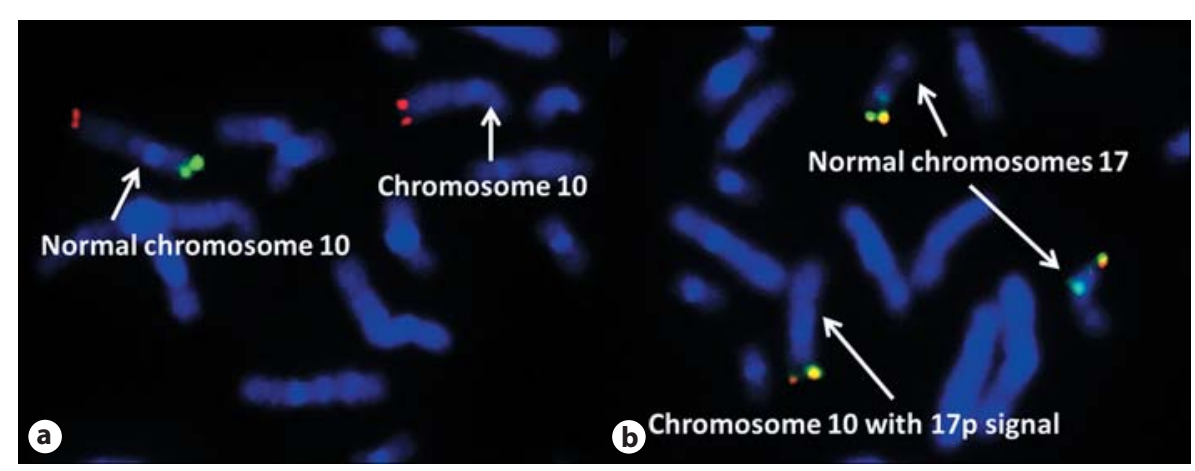

\section{Materials and Methods}

Peripheral blood samples were taken from the patient and from her parents to culture peripheral blood lymphocytes. Chromosome analysis was performed by conventional GTG-banding (550 bands). FISH analysis for all 41 subtelomeric regions was also performed using the ToTelVysion Multi-color DNA probe mixture (Vysis, Inc., USA). A minimum of 50 metaphases were analyzed under an Axio Images (Carl Zeiss) fluorescence microscope equipped with the appropriate filters. The images were captured with specific ISIS (Meta Systems) software. Finally, aiming to delimit and to analyze the involved segments, we performed a 60,000 oligonucleotide array-CGH, sourced from the University of California, Santa Cruz (UCSC), Calif., USA, hg18 (NCBI Build 36), March 2006, probe spacing: $41 \mathrm{~KB}$ overall median probe spacing (33 KB in Refseq genes) (Agilent Technologies; Santa Clara, Calif., USA). The research was prospectively reviewed and approved by a duly constituted ethics committee.

\section{Results and Discussion}

Standard cytogenetic GTG-banding analysis (550 bands) revealed a normal karyotype of the patient and her parents. However, due to the dysmorphic features present in the girl, we performed a subtelomeric FISH analysis on the patient and her parents. Analysis showed the absence of 1 subtelomeric signal of chromosome 10p (partial monosomy) and 1 extra signal for chromosome 17p (partial trisomy), resulting in an unbalanced $10 \mathrm{p} ; 17 \mathrm{p}$ translocation in the girl (fig. 3). Array-CGH analysis showed a heterozygous deletion of $4.43 \mathrm{Mb}$ on chromosome $10 \mathrm{p}$ and a single-copy gain of $3.22 \mathrm{Mb}$ on chromosome $17 \mathrm{p}$ (fig. 4): $46, X X$.arr10p15.3p15.1(138,206-4,574,436)x 1, $17 \mathrm{p} 13.3(87,009-3,312,600) \times 3$ in the patient. Additionally, subtelomeric FISH analysis revealed a balanced 10p;17p translocation in her father, indicating that he is the carrier of the alteration (fig. 5). The father's karyotype was established as: ish $\mathrm{t}(10 ; 17)(\mathrm{p} 15.3-, \mathrm{p} 13.3 \pm ; \mathrm{p} 13.3-, \mathrm{p} 15.3 \pm)$ (Z96139-,282M16/SP6士; Z96139-,282M16/SP6士).

Array-CGH analysis did not demonstrate deletions or duplications in the patient's parents. The region deleted on chromosome 10p involved 14 genes, while the gain in chromosome 17 resulted in the duplication of 61 genes (online supplementary fig. 1 and 2, www. karger.com/doi/10.1159/000339639). Interestingly, this duplication involves the complete MDS region, and, to date, only 6 cases have been reported with this type of 


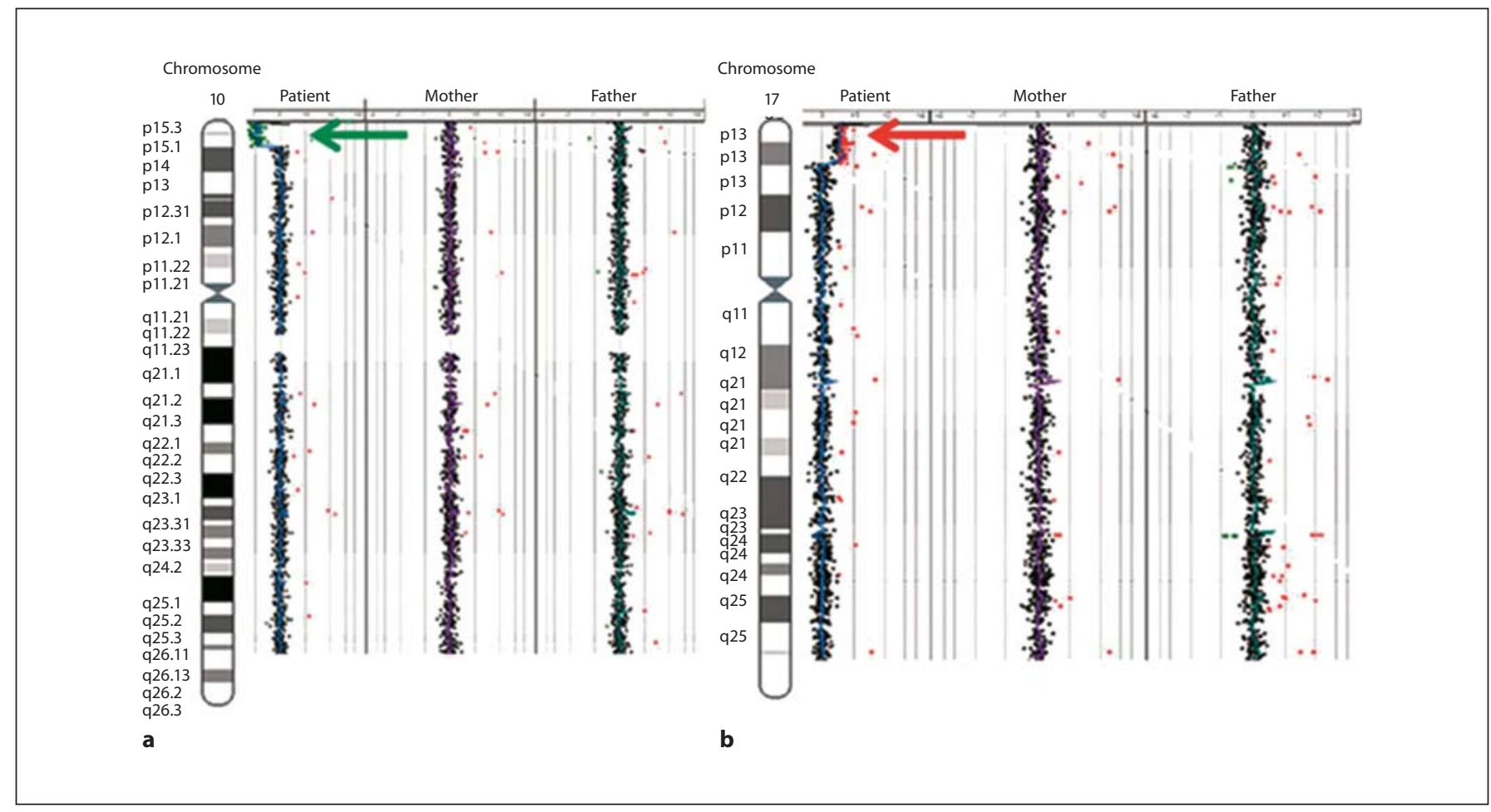

Fig. 4. Graphic representation of the involved regions of chromosomes 10 and 17. a Monoallelic deletion of $4.43 \mathrm{Mb}$ on chromosome $10 \mathrm{p}$ detected in the patient. b Single-copy gain of $3.22 \mathrm{Mb}$ on chromosome $17 \mathrm{p}$ found in the girl.

Fig. 5. Translocation $10 p ; 17 p$ detected in the father with FISH for subtelomeric regions. The image shows one normal chromosome 10 and one chromosome 10 involved in a balanced translocation with chromosome 17.

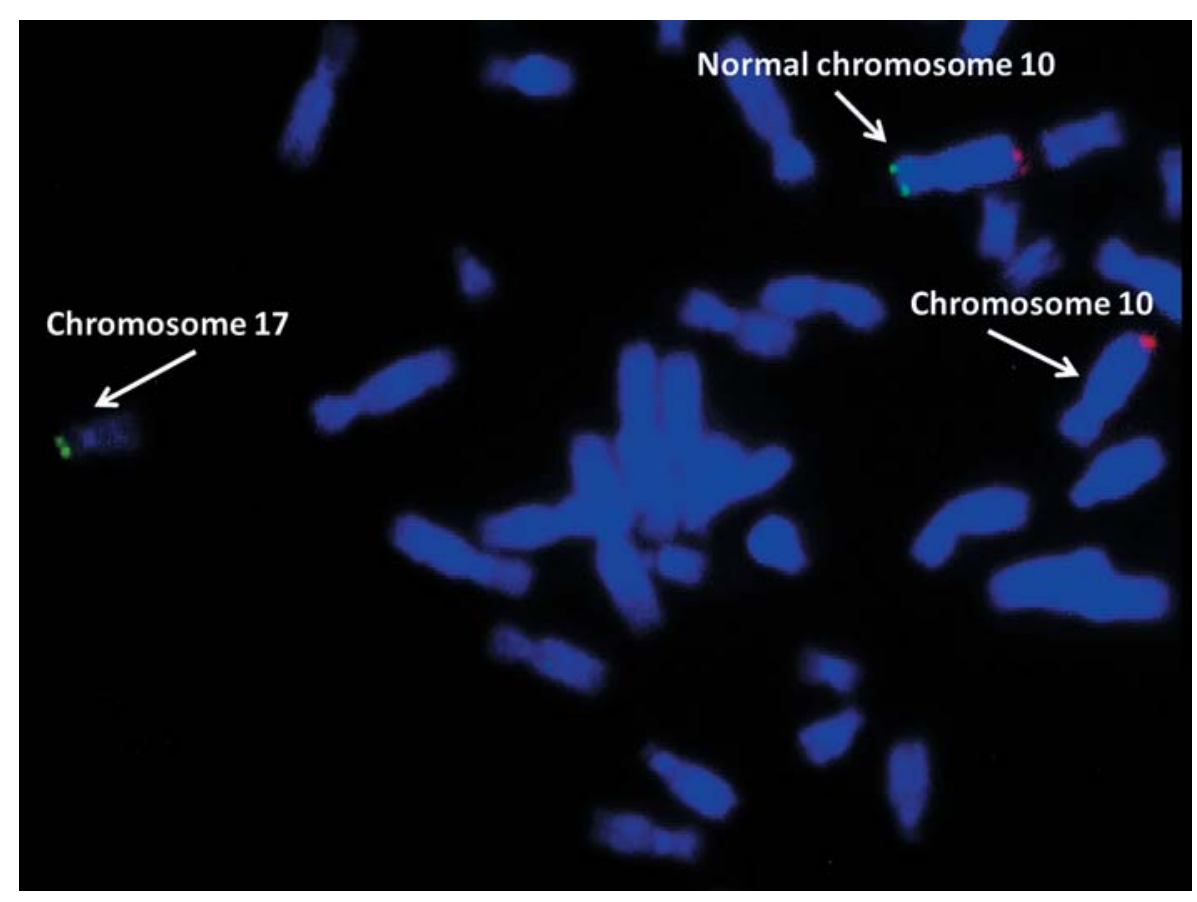


Table 1. Comparison of clinical features of the 7 patients with duplication of the $17 \mathrm{p} 13.3$ from the literature and contrasted with our patient

\begin{tabular}{|c|c|c|c|c|c|c|c|}
\hline & $\begin{array}{l}\text { Bi et al., } \\
\text { [2009] } \\
\text { Patient } 7\end{array}$ & $\begin{array}{l}\text { Roos et al., } \\
{[2009]} \\
\text { Patient } 1\end{array}$ & $\begin{array}{l}\text { Roos et al., } \\
\text { [2009] } \\
\text { Patient } 2\end{array}$ & $\begin{array}{l}\text { Roos et al., } \\
\text { [2009] } \\
\text { Patient } 3\end{array}$ & $\begin{array}{l}\text { Bruno et al., } \\
{[2010]} \\
\text { Patient } 10\end{array}$ & $\begin{array}{l}\text { Hyon et al., } \\
\text { [2011] } \\
\text { Patient } 1\end{array}$ & Our patient \\
\hline Size of duplication, $\mathrm{Mb}$ & 3.6 & 1.8 & 3.0 & 4.0 & 2.0 & 4.22 & 3.22 \\
\hline Inheritance & de novo & de novo & de novo & de novo & de novo & $?$ & from the father \\
\hline Age at diagnosis, years & 10 & 14 & 1 & 1 & 6.5 & 13 & 0.5 \\
\hline Gender & $\mathrm{F}$ & M & $\mathrm{F}$ & M & M & $\mathrm{F}$ & $\mathrm{F}$ \\
\hline Birth height, $\mathrm{cm}$ & 53 & 53 & N/A & 50 & normal & normal & 51 \\
\hline Birth weight, $g$ & 3,060 & 3,350 & 4,200 & 3,380 & normal & normal & 3,000 \\
\hline Current height & $+1 \mathrm{SD}$ & $+3.5 \mathrm{SD}$ & normal & $+1 \mathrm{SD}$ & normal & $+1 \mathrm{SD}$ & 50-75th percentile \\
\hline Current weight & $+2 \mathrm{SD}$ & $+1 \mathrm{SD}$ & $-2 \mathrm{SD}$ & $+1 \mathrm{SD}$ & normal & $+1 \mathrm{SD}$ & 25th percentile \\
\hline Brain imaging results & $\begin{array}{l}\text { reduced brain size, } \\
\text { corpus callosum } \\
\text { hypoplasia, } \\
\text { cerebellar agenesia }\end{array}$ & $\begin{array}{l}\text { no apparent } \\
\text { brain alterations }\end{array}$ & $\mathrm{N} / \mathrm{A}$ & $\begin{array}{l}\text { dilated lateral ventricles, } \\
\text { corpus callosum agenesis, } \\
\text { abnormal signal intensities } \\
\text { of white matter }\end{array}$ & N/A & $\begin{array}{l}\text { no apparent } \\
\text { brain alterations }\end{array}$ & $\begin{array}{l}\text { cortical atrophy } \\
\text { and hypoplasia of } \\
\text { corpus callosum }\end{array}$ \\
\hline
\end{tabular}

$\mathrm{SD}=$ Standard deviation; N/A = Not available

Table 2. Phenotype of the 7 patients with duplication of MillerDieker completed region

Cases from Our the literature patient

Craniofacial features

Hypotonic face

Broad midface

Low-set ears

Frontal bossing

Triangular chin

Down-slanting palpebral fissures

Upward palpebral fissures

Hypertelorism

Broad nasal root

Strabismus

Small mouth

Short neck

Cleft lip and palate

Neurological features

Hypotonia

Speech delay

Delay in mental development

Abnormal behavior

Reduced sensitivity to pain

Other features

Clinodactyly

Hip luxation

Equinovalgus, both feet

Recurrent infections

\begin{tabular}{ll}
$4 / 6$ & - \\
$3 / 6$ & - \\
$2 / 6$ & - \\
$3 / 6$ & - \\
$3 / 6$ & + \\
$4 / 6$ & - \\
$1 / 6$ & + \\
$4 / 6$ & + \\
$4 / 6$ & + \\
$1 / 6$ & + \\
$3 / 6$ & - \\
$2 / 6$ & + \\
$1 / 6$ & - \\
$5 / 6$ & \\
$4 / 6$ & - \\
$5 / 6$ & + \\
$6 / 6$ & + \\
$2 / 6$ & + \\
$2 / 6$ & - \\
$1 / 6$ & + \\
$1 / 6$ & + \\
$5 / 6$ & + \\
\hline
\end{tabular}

Bi et al., [2009]; Roos et al., [2009] Bruno et al., [2010]; Hyon et al., [2011]. duplication [Ravana et al., 2006; Kirchhoff et al., 2007; Bi et al., 2009; Roos et al., 2009; Bruno et al., 2010; Hyon et al., 2011]. All 17p13.3 duplications reported to date are the products of no-recurring rearrangements, with different breakpoints (3-4 Mb) distal to 17p3.3 [Bi et al., 2009; Bruno et al., 2010; Hyon et al., 2011]; therefore, the regions involved vary from patient to patient. Of the different genes located in the MDS region, the PAFAH1B1 and $Y W A H E$ genes are those that are most frequently studied. Patients with duplication or triplication of the PAFAH1B1 gene have dysgenesis of the corpus callosum and cerebellar atrophy, resulting in smaller brains, mainly in terms of the occipital cortex [Bi et al., 2009]. Related with this, mice with overexpression of the Pafahlb1 gene show severe alterations during brain development that result in animals with small brains [Chong et al., 1996, 1997; Cardoso et al., 2000, 2003; Lindardopoulou et al.,2005]. Because duplication of 17p13.3 varies in size, Bruno et al. [2010] proposed 2 different groups of patients with distinct types of microduplication and distinct phenotypic features. Meanwhile, a third group of patients has been proposed who possess duplication of the complete MDS region [Hyon et al., 2011]. Interestingly, our patient possesses complete duplication of this region, sharing features described for this type of patient (tables 1 and 2). However, because the patient exhibits a combination of 2 imbalances, which are the result of malsegregation of a parental balanced translocation, many features might be attributed to genes that are lost in chromosome 10p (table 3). 
Table 3. Clinical features reported in literature for patients with partial 10p14 $\rightarrow$ pter monosomies in contrast with clinical features present in our patient

\begin{tabular}{ll}
$\begin{array}{ll}\text { Clinical features reported for } \\
\text { partial 10p } \rightarrow \text { pter monosomies }\end{array}$ & $\begin{array}{l}\text { Features in } \\
\text { our patient }\end{array}$ \\
\hline Mental retardation (psychomotor delay) & + \\
Microcephaly & + \\
Micrognathia & - \\
Small nose with rounded tip and broad nasal root & + \\
Triangular face & - \\
Retrognathia & - \\
Hypoplastic midface & + \\
Frontal bossing & - \\
Small palpebral fissures & - \\
Upward palpebral fissures & + \\
Dysmorphic ears (cup-shaped, with an & \\
$\quad$ absent-superior fork of the antihelix) & + \\
Hand and foot dysplasias & + \\
Cardiac defects & - \\
Urogenital anomalies & - \\
Brain anomalies & + \\
Seizures & - \\
\hline
\end{tabular}

Fryns et al., [1981]; Shapira et al. [1994]; Roos et al., [2006]; Battaglia et al., [2007]; Bruno et al., [2010]; Lindstrand et al., [2010]; Faletra et al., [2011]; Hyon et al. [2011].

The majority of patients with a duplicated MSD region have been reported with a relative increase of body weight and height and recurrent middle ear infections, features that are absent in our patient. Also, our patient presents abnormalities in hands and feet, showing long fingers, bilateral equinovalgus and clinodactyly of the 4th toes, with dysplastic concave toenails, features described for some patients with duplication of 17p13.3 [Bi et al., 2009; Bruno et al., 2010; Armour et al., 2011; Hyon et al., 2011]. In addition, our patient has severe visual dysfunction and immaturity of auditory brainstem-evoked responses, which might be associated with the reduction of the visual cortex found in the 17p13.3 duplication. However, visual and auditory dysfunctions are highly conserved among all patients with partial monosomy 10p [Bourrouillou et al., 1981; Fryns et al., 1981; Battaglia et al., 2007; Lindstrand et al., 2010].

Two different critical regions of chromosome 10p have been proposed. Loss of chromosome region 10p13-14 has been described in patients with DGSII, characterized by the presentation of heart defects and T-cell deficiency [Schuffenhauer et al., 1995; Daw et al., 1996; Dasoiuki et al., 1997; Lichtner et al., 2000]. Similarly, haploinsufficiency of the region 10 p14 $\rightarrow$ pter, distal to DGCR2, results in

hypoparathyroidism, sensorineural deafness and renal anomaly, features that determine the HDR syndrome [Van Esch et al., 2000; Fukami et al., 2011]. In this region, it has been described that the GATA3 gene, which is involved in the embryonic development of the parathyroids, auditory system and kidneys, plays a critical role in the development of different neural populations within the mammalian central nervous system [Van Esch et al., 2000; Karunaratne et al., 2002; Lindstrand et al., 2010]. In the embryonic midbrain, GATA3 expression correlates with the development of the optic tectum [Kornhauser et al., 1994], while in the developing hindbrain, loss of GATA3 affects differentiation of the vestibuloacoustic efferent neurons and migration of the facial branchiomotor neurons [Pata et al., 1999]. Interestingly, although we did not detect GATA3 gene deletion with array-CGH in our patient, she does exhibit hearing and visual alterations. In this respect, in both Drosophila melanogaster and mice, it has been demonstrated that during specific development stages, the disco-interacting protein 2 gene (DIP2C) is highly expressed in distinct brain regions, including the optic and otic vesicles. Therefore, deletion of the 10p15.3 region, which includes the DIP2C gene, in our patient might be associated with the severe visual dysfunction and immaturity of the auditory brainstem-evoked responses observed [Mukhopadhyay et al., 2002]. Description of the clinical and molecular characteristics of our patient contributes to confirming and further defining the characteristics associated with the duplication of the entire MDS region and the partial monosomy of chromosome 10p15.3.

\section{Acknowledgements}

We thank the patient and her parents for their participation in this research, Rosalba Sevilla-Montoya M.D., for her clinical support, Sara Frías Vázquez, for useful comments and advice, and Maggie Brunner, M.A., for English assessment. This work was supported by grants to R.R.E.-G., including grant 207170, grant Salud-2005-01-13947 from Consejo Nacional de Ciencia y Tecnología (CONACYT-México) and FIS 2006/1A/025 (2005/3603/037) Coordinación de Investigación en Salud, IMSS. Posgrado Ciencias Biológicas, Universidad Nacional Autónoma de México (UNAM).

References

Mol Syndromol 2012;3:82-88

\footnotetext{
Armour CM, Bulman DE, Jarinova O, Rogers RC, Clarkson KB, et al: 17p13.3 microduplications are associated with split-hand/foot malformation and long-bone deficiency (SHFLD). Eur J Hum Genet 19:1144-1151 (2011).

Assadi AH, Zhang G, Beffert U, McNeil RS, Renfro AL, et al: Interaction of reelin signaling and Lis1 in brain development. Nat Genet 35: $270-276$ (2003).
} 
- Battaglia A, Novelli A, Ceccarini C, Bernardini L, Carey JC: Subtelomeric analysis detects a familial $10 p ; 12 p$ rearrangement in two relatives with a distinct syndrome. Am J Med Genet A 143:184-188 (2007).

- Bi W, Sapir T, Shchelochkov OA, Zhang F, Withers MA, et al: Increased LIS1 expression affects human and mouse brain development. Nat Genet 41:168-177 (2009).

- Bourrouillou G, Colombies P, Gallegos D, Manelfe C, Rochiccioli P: Partial monosomy $10 \mathrm{p}$ in a case investigated with tomodensitometry (author's translation) [in French]. Ann Genet 24:61-64 (1981).

-Bruno DL, Anderlid BM, Lindstrand A, van Ravenswaaij-Arts C, Ganesamoorthy D, et al: Further molecular and clinical delineation of co-locating 17p13.3 microdeletions and microduplications that show distinctive phenotypes. J Med Genet 47:299-311 (2010).

-Cardoso C, Leventer RJ, Matsumoto N, Kuc JA, Ramocki MB, et al: The location and type of mutation predict malformation severity in isolated lissencephaly caused by abnormalities within the LIS1 gene. Hum Mol Genet 9: 3019-3028 (2000).

-Cardoso C, Leventer RJ, Ward HL, Toyo-Oka K, Chung J, et al: Refinement of a $400-\mathrm{kb}$ critical region allows genotypic differentiation between isolated lissencephaly, Miller-Dieker syndrome, and other phenotypes secondary to deletions of 17p13.3. Am J Hum Genet 72:918-930 (2003).

-Chong SS, Tanigami A, Roschke AV, Ledbetter DH:14-3-3 Epsilon has no homology to LIS1 and lies telomeric to it on chromosome 17p13.3 outside the Miller-Dieker syndrome chromosome region. Genome Res 6:735-741 (1996).

-Chong SS, Pack SD, Roschke AV, Tanigami A, Carrozzo R, et al: A revision of the lissencephaly and Miller-Dieker syndrome critical regions in chromosome 17p13.3. Hum Mol Genet 6:147-155 (1997).

Dasouki M, Jurecic V, Phillips JA 3rd, Whitlock JA, Baldini A: DiGeorge anomaly and chromosome 10p deletions: one or two loci? Am J Med Genet 73:72-75 (1997).

$\checkmark$ Daw SC, Taylor C, Kraman M, Call K, Mao J, et al: A common region of $10 \mathrm{p}$ deleted in DiGeorge and velocardiofacial syndromes. Nat Genet 13:458-460 (1996).

De Vries BB: Telomeres: a diagnosis at the end of the chromosomes. J Med Genet 40:385-398 (2003).

Faletra F, Devescovi R, Pecile V, Fabretto A, Carrozzi $M$, Gasparini P: A new case of duplication of the MDS region identified by highdensity SNP arrays and a review of the literature. J Appl Genet 52:77-80 (2011).

- Fukami M, Muroya K, Miyake T, Iso M, Kato F, et al: GATA3 abnormalities in six patients with HDR syndrome. Endocr J 58:117-121 (2011).

-Fryns JP, De Muelenaere A, Van den Berghe H: Distal 10p deletion syndrome. Ann Genet 24:189-190 (1981).
Hyon C, Marlin S, Chantot-Bastaraud S, Mabboux P, Beaujard MP, et al: A new 17p13.3 microduplication including the PAFAH1B1 and $Y W H A E$ genes resulting from an unbalanced X;17 translocation. Eur J Med Genet 54:287-291 (2011).

Karunaratne A, Hargrave M, Poh A, Yamada T: GATA proteins identify a novel ventral interneuron subclass in the developing chick spinal cord. Dev Biol 249:30-43 (2002).

Kinoshita Y, Tanaka Y, Yasuhara A, Matsuzaki S, Kuriki H, Kobayashi Y: A case of deletion of the short arm of chromosome 10 with severe hearing loss and brainstem dysfunction. Am J Perinat 4:299-301 (1992).

Kirchhoff M, Bisgaard AM, Bryndorf T, Gerdes T: MLPA analysis for a panel of syndromes with mental retardation reveals imbalances in $5.8 \%$ of patients with mental retardation and dysmorphic features, including duplications of the Sotos syndrome and WilliamsBeuren syndrome regions. Eur J Med Genet 50:33-42 (2007).

Knight SJ, Flint J: Perfect endings: a review of subtelomeric probes and their use in clinical diagnosis. J Med Genet 37:401-409 (2000).

Kornhauser JM, Leonard MW, Yamamoto M, LaVail JH, Mayo KE, Engel JD: Temporal and spatial changes in GATA transcription factor expression are coincident with development of the chicken optic tectum. Brain Res Mol Brain Res 23:100-110 (1994).

-Ledbetter DH, Martin CL: Cryptic telomere imbalance: a 15-year update. Am J Med Genet C Semin Med Genet 145C:327-334 (2007).

-Lichtner P, König R, Hasegawa T, Van Esch H, Meitinger T, Schuffenhauer S: An HDR (hypoparathyroidism, deafness, renal dysplasia) syndrome locus maps distal to the DiGeorge syndrome region on 10p13/14. J Med Genet 37:33-37 (2000).

Linardopoulou EV, Williams EM, Fan Y, Friedman C, Young JM, Trask BJ: Human subtelomeres are hot spots of interchromosomal recombination and segmental duplication. $\mathrm{Na}$ ture 437:94-100 (2005).

Lindstrand A, Malmgren H, Verri A, Benetti E, Eriksson M, et al: Molecular and clinical characterization of patients with overlapping 10p deletions. Am J Med Genet A 152A:1233-1243 (2010).

Lu X, Shaw CA, Patel A, Li J, Cooper ML, et al: Clinical implementation of chromosomal microarray analysis: summary of 2513 postnatal cases. PLoS One 2:e327 (2007).

Mefford HC, Trask BJ: The complex structure and dynamic evolution of human subtelomeres. Nat Rev Genet 3:91-102 (2002).

Mukhopadhyay M, Pelka P, DeSousa D, Kablar $\mathrm{B}$, Schindler A, et al: Cloning, genomic organization and expression pattern of a novel Drosophila gene, the disco-interacting protein 2 (dip2), and its murine homolog. Gene 293:59-65 (2002).
Pata I, Studer M, van Doorninck JH, Briscoe J, Kuuse $S$, et al: The transcription factor GATA3 is a downstream effector of Hoxb1 specification in rhombomere 4. Development 126: 5523-5531(1999).

-Ravnan JB, Tepperberg JH, Papenhausen P, Lamb AN, Hedrick J, et al: Subtelomere FISH analysis of 11688 cases: an evaluation of the frequency and pattern of subtelomere rearrangements in individuals with developmental disabilities. J Med Genet 43:478-489 (2006).

Riethman H, Ambrosini A, Paul S: Human subtelomere structure and variation. Chromosome Res 13:505-515 (2005).

Roos A, Rudnik-Schöneborn S, Eggermann K, Eggermann T, Senderek J, et al: Submicroscopic unbalanced translocation resulting in del10p/dup13q detected by subtelomere FISH. Eur J Med Genet 49:505-510 (2006).

Roos L, Jønch AE, Kjaergaard S, Taudorf K, Simonsen $\mathrm{H}$, et al: A new microduplication syndrome encompassing the region of the Miller-Dieker (17p13 deletion) syndrome. J Med Genet 46:703-710 (2009).

-Saccone S, De Sario A, Della Valle G, Bernardi G: The highest gene concentrations in the human genome are in telomeric bands of metaphase chromosomes. Proc Natl Acad Sci USA 89:4913-4917 (1992).

Schinzel A: Catalogue of Unbalanced Chromosome Aberrations in Man, ed 2 (De Gruyter, Berlin/New York 2001).

Schuffenhauer S, Seidel H, Oechsler H, Belohradsky B, Bernsau U, et al: DiGeorge syndrome and partial monosomy 10p: case report and review. Ann Genet 38:162-167 (1995).

- Suciu S, Nanulescu M: A case of 10p- syndrome. Ann Genet 26:109-111(1983).

-Shapira M, Borochowitz Z, Bar-El H, Dar H, Etzioni A, Lorber A: Deletion of the short arm of chromosome 10 (10p13): report of a patient and review. Am J Med Genet 52:3438 (1994).

-Shchelochkov OA, Cheung SW, Lupski JR: Genomic and clinical characteristics of microduplications in chromosome 17. Am J Med Genet A 152A:1101-1110 (2010).

Toyo-oka K, Shionoya A, Gambello MJ, Cardoso C, Leventer R, et al: 14-3-3epsilon is important for neuronal migration by binding to NUDEL: a molecular explanation for MillerDieker syndrome. Nat Genet 34:274-285 (2003).

Wu Y, Ji T, Wang J, Xiao J, Wang H, et al: Submicroscopic subtelomeric aberrations in Chinese patients with unexplained developmental delay/mental retardation. BMC Med Genet 11:72 (2010).

-Van Esch H, Groenen P, Nesbit M, Schuffenhauer S, Lichtner P, et al: GATA3 haplo-insufficiency causes human HDR syndrome, Nature 406:419-422 (2000).

-Verri AP, Maraschio P, Uggetti C, Pucci E, Ronchi G, et al: Late diagnosis in severe and mild intellectual disability in adulthood. J Intellect Disabil Res 48:679-86 (2004). 